\title{
Pemberdayaan Perawat dalam Penerapan Nurse Early Warning System untuk Memantau Kondisi Pasien di Rumah Sakit
}

\author{
Junaedi Yunding ${ }^{1}$, Masyita Haerianti ${ }^{2}$, Evidamayanti ${ }^{3}$, Evawaty ${ }^{4}$, Indrawati ${ }^{5}$ \\ 1,2,3,4,5 Fakultas Ilmu Kesehatan Universitas Sulawesi Barat, Majene, Indonesia \\ Email : yundingj@unsulbar.ac.id
}

Submitted : 09/04/2020

Accepted: 20/04/2020

Published:16/06/2020

\begin{abstract}
Severe adverse events such as cardiac arrest and death are often marked by abnormal vital signs a few hours before the event. Majene Regional General Hospital is the only hospital in the Majene Regency and is a reference center for all puskesmas in the Majene and surrounding districts. As a health service institution that organizes health services, it is closely related to the responsibility of providing emergency services. The Nurse Early Warning System (NEWS) is a development in emergency services for patients treated in hospitals, which serves as an early detection tool so that if there is a decrease in the patient's condition it can be known earlier can be handled more quickly. The purpose of this activity is to increase the knowledge and skills of nurses in the application of the nurse early warning system (NEWS) in monitoring the condition of patients in the care room. The implementation method starts from identifying the problem, delivering material about NEWS, demonstrating the assessment of the patient's condition and the nurse's independent practice in using NEWS. The evaluation results of this activity are the increase in knowledge and skills of nurses using NEWS in monitoring the condition of patients in the care room.
\end{abstract}

Keywords: assistance, early warning system, nurse

\begin{abstract}
Abstrak
Kejadian buruk yang parah seperti henti jantung dan kematian seringkali ditandai oleh tanda-tanda vital yang abnormal beberapa jam sebelum kejadian. Rumah Sakit Umum Daerah (RSUD) Majene merupakan satu-satunya Rumah Sakit yang berada di wilayah Kabupaten Majene dan menjadi pusat rujukan bagi seluruh puskesmas yang ada di wilayah kabupaten majene dan sekitarnya. Sebagai institusi pelayanan kesehatan yang menyelenggarakan pelayanan kesehatan, terkait erat dengan tanggung jawab memberikan pelayanan gawat darurat. Nurse Early Warning System (NEWS) merupakan pengembangan dalam layanan kegawatdaruratan pasien yang dirawat di rumah sakit, yang berfungsi sebagai alat deteksi dini sehingga apabila terjadi penurunan kondisi pasien dapat diketahui lebih awal dapat ditangani lebih cepat. Tujuan dari kegiatan ini yaitu Meningkatnya pengetahuan dan keterampilan perawat dalam penerapan nurse early warning system (NEWS) dalam memonitoring kondisi pasien di ruang perawatan. Metode pelaksanaan dimulai dari idetifikasi masalah, penyampaian materi tentang NEWS, demostrasi penilaian kondisi pasien serta praktek mandiri perawat dalam menggunakan NEWS. Hasil evaluasi dari kegiatan ini yaitu meningkatnya pengetahuan dan keterampilan perawat menggunakan NEWS dalam memantau kondisi pasien diruang perawatan.
\end{abstract}

Kata kunci : nurse early warning system, pendampingan, perawat.

\section{PENDAHULUAN}

Kejadian gawat darurat bisa terjadi kepada siapa, kapan dan dimana saja, kondisi ini menuntut kesiapan petugas kesehatan untuk mengantisipasi kejadian itu. Kejadian buruk yang parah seperti henti jantung dan kematian seringkali ditandai oleh tanda-tanda vital yang abnormal beberapa jam sebelum kejadian. Hal ini membutuhkan jalur yang terorganisir dan memicu pendekatan pengenalan dini dan respons terhadap perubahan kondisi pasien (Mathukia, Fan, Vadyak, Biege \& Krishnamurthy, 2015).

Rumah Sakit Umum Daerah (RSUD) Majene merupakan satu-satunya Rumah Sakit yang berada di wilayah Kabupaten Majene dan menjadi pusat rujukan bagi 
seluruh puskesmas yang ada di wilayah kabupaten majene dan sekitarnya. Sebagai institusi pelayanan kesehatan yang menyelenggarakan pelayanan kesehatan, terkait erat dengan tanggung jawab memberikan pelayanan gawat darurat.

Terjaminnya kualitas mutu pelayanan dalam pengelolaan pasien kritis maupun pasien yang mengalami perburukan sampai henti jantung tidak terlepas dari kualitas SDM (Sumber Daya Manusia), sarana prasarana yang tersedia maupun proses evaluasi dan monitoring dalam pelaksanaannya. Oleh karena itu perangkat hukum dan administrasi harus segera dipenuhi, peningkatan kualitas SDM dengan pelatihan harus dilakukan, pemenuhan alat peraga pelatihan dengan kolaborasi diklat, pemenuhan alat dan obat emergency, serta evaluasi dengan para PIC (Person in Charge) dalam komite mutu untuk mendapatkan data yang dibutuhkan. EWS juga tidak hanya dilakukan kepada pasien biasa, tetapi juga mencakup pada populasi khusus, misalnya anak-anak atau pasien dengan kehamilan (Winarno, 2018).

Nurse Early Warning System (NEWS) merupakan pengembangan dalam layanan kegawatdaruratan pasien yang dirawat di rumah sakit, yang berfungsi sebagai alat deteksi dini sehingga apabila terjadi penurunan kondisi pasien dapat diketahui lebih awal dapat ditangani lebih cepat. NEWS didasarkan atas penilaian terhadap perubahan keadaan pasien melalui pengamatan yang sistematis terhadap semua perubahan fisiologi pasien. Sistem ini merupakan konsep pendekatan proaktif untuk meningkatkan keselamatan pasien dan hasil klinis pasien yang lebih baik dengan standarisasi pendekatan asesmen dan menetapkan skoring parameter fisiologis yang sederhana. Kesinambungan pelayanan harus dilakukan baik pasien dalam keadaan yang stabil maupun saat pasien dalam kondisi buruk. Deteksi dini, ketepatan waktu merespon, dan kompetensi respon klinis merupakan serangkaian kegiatan yang harus dilakukan untuk optimalisasi hasil klinis (Smith, Chiovaro, O'Neil, et al 2014).

Permasalahan krusial yang biasanya dihadapi adalah kondisi pasien yang memburuk di ruang perawaan. Kondisi ini mengharuskan perawat untuk dapat mengidentifikasi kondisi pasien untuk melakukan penatalaksanaan yang tepat.

\section{TARGET DAN LUARAN}

\section{Target}

Target dalam kegiatan pengabdian kepada masyarakat ini adalah: Perawat di rumah Sakit Umum Daerah Kabupaten Majene

\section{Luaran}

a. Gambaran demografi perawat di RSUD Kab. Majene

b. Pengetahuan dan keterampilan perawat dalam penerapan nurse early warning system (NEWS) dalam memonitoring kondisi pasien di ruang perawatan,

c. Kemampuan dalam hal penentuan kondisi pasien serta penanganan lanjutan pasien di ruang perawatan.

\section{METODE PELAKSANAAN}

1. Identifikasi masalah mitra melalui kunjungan awal dan persiapan orientasi lapangan.

2. Pengorganisasian mitra dalam kegiatan Pelatihan dengan metode ceramah dan diskusi yang dilaksanakan langsung di aula Rumah Sakit Umum Daerah (RSUD) Kab. Majene.

3. Demonstrasi dan Praktek

4. Pelaksanaan evaluasi dilakukan secara langsung sebanyak dua kali, yaitu: pada akhir pelatihan dilakukan untuk mengetahui tingkat pengetahuan materi yang disampaikan, dan pada akhir demonstrasi/praktek.

\section{Pelaksanaan kegiatan}

1. Sabtu, 26 Oktober 2019

Penyelenggaraan

Pelaksanaan dilaksanakan di aula RSUD Kab. 
Majene melalui kegiatan penyuluhan dan pelatihan dengan metode ceramah dan diskusi. Penyuluhan di hadiri oleh direktur RSUD Kab Majene, Kepala Ruangan serta ketua tim di masing masing ruangan. Peserta penyuluh berjumlah 35 perawat dan Untuk memudahkan peserta memahami materi yang disampaikan penyuluh menggunakan alat multi media (LCD) proyektor dan materi yang diberikan yaitu:

- Materi Monitoring Kondisi pasien menggunakan Nurse Early warning System (NEWS)

- Optimalisasi Penggunaan NEWS dalam memonitoring kondisi pasien di ruang perawatan

- Setelah dilakukan penyuluhan dan pelatihan kemudian diakhiri dengan melakukan evaluasi terhadap peserta penyuluhan dan pelatihan untuk mengetahui tingkat pengetahuan tentang materi yang disampaikan.

2. Sabtu, 26 Oktober 2019

Melakukan

Demonstrasi/Praktek penilaian skore kondisi pasien menggunakan form NEWS di ruangan Dahlia RSUD Kab. Majene. Demonstrasi/praktek diakhiri dengan melakukan evaluasi terhadap peserta untuk mengetahui apakah perawat /peserta tersebut mampu mengkasifikasikan pasien sesuai dengan kategori dan alur Triage. Evaluasi dilakukan dengan melibatkan langsung pasien yang ada pada saat itu. Hasil evaluasi menunjukkan bahwa setelah melakukan demonstrasi perawat mampu melakukan tekhnik pemilihan pasien sesuai dengan kategorinya.

3. Minggu, 27 Oktober 2019

Mengevaluasi tindakan mandiri penilaian kondisi pasien oleh perawat di ruang interna dan perawatan anak

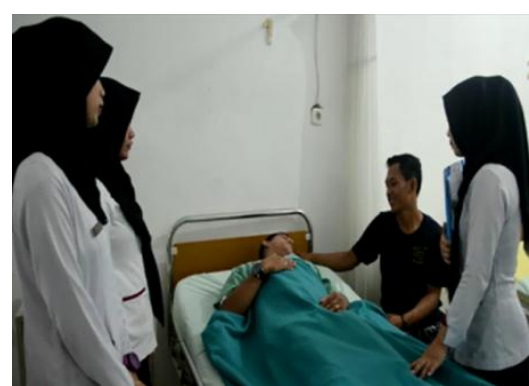

Gambar 1 Penilaian Kondisi Pasien

\section{HASIL DAN PEMBAHASAN}

Kegiatan pengabdian ini di laksanakan selama 2 hari dengan harapan perawat di RSUD Kab. Majene dapat memahami serta mampu menggunakan Form NEWS dalam mengidentifikasi kondisi pasien di ruang perawatan.

Jumlah perawat yang mengikuti pelatihan ini sebanyak 31 orang dengan gambaran sebagai berikut :

Tabel 1. Distribusi Perawat berdasarkan Jenis Kelamin di RSUD Kab. Majene

\begin{tabular}{ccc}
\hline Jenis Kelamin & $(\mathrm{n})$ & $(\%)$ \\
\hline Laki - laki & 19 & 61,3 \\
Perempuan & 12 & 38,7 \\
\hline Total & 31 & 100 \\
\hline
\end{tabular}

Tabel 2. Distribusi Perawat berdasarkan Pendidikan di RSUD Kab. Majene

\begin{tabular}{ccc}
\hline Tingkat & $(\mathrm{n})$ & $(\%)$ \\
Pendidikan & 18 & 58,1 \\
D3 & 13 & 41,9 \\
\hline Keperawatan & 31 & 100 \\
\hline Ters & 13 &
\end{tabular}

Format News yang di gunakan untuk menilai kondisi pasien di ruang perawatan sebagai berikut :

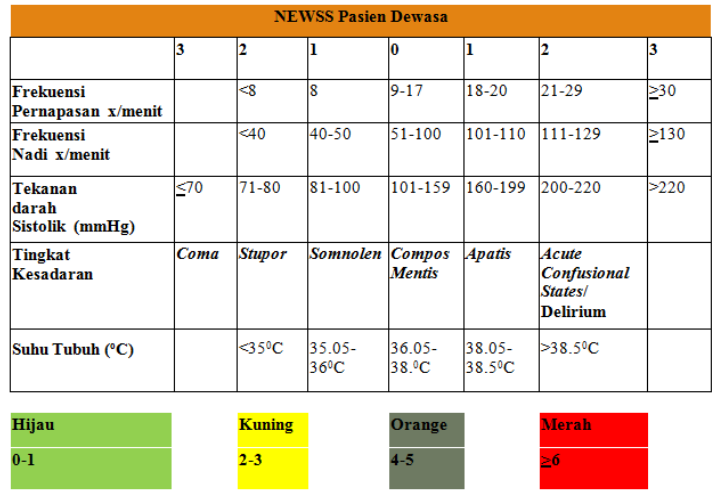

Gambar 2 Form NEWS 


\section{KESIMPULAN DAN SARAN}

\section{Kesimpulan}

Nurse Early Warning System (NEWS) merupakan pengembangan dalam layanan kegawatdaruratan pasien yang dirawat di rumah sakit, yang berfungsi sebagai alat deteksi dini sehingga apabila terjadi penurunan kondisi pasien dapat diketahui lebih awal dapat ditangani lebih cepat. Rumah Sakit Umum Daerah ( RSUD ) Majene merupakan salah satu fasilitas pelayanan kesehatan wilayah Kab. Majene yang memiliki Ruang perawatan dimana pasien sangat berisiko mengalami perburukan. Setelah Penyelenggaraan Kegiatan Pemberdayaan Perawat menggunakan NEWS dalam mendeteksi perburukan pasien. Perawat sudah memiliki pengetahuan tentang konsep penilaian perburukan kondisi pasien di ruang perawatan serta mampu menentukan kondisi dan penanganan pasien dengan tepat

\section{Saran}

Dengan Tingginya angka kejadian kasus kegawatdaruratan di rumah sakit, perawat harus memiliki kemampuan untuk mengetahuai kondisi serta mengatasi pasien yang mengalami perburukan. Diharapkan perawat pelaksana bisa mengembangkan penggunaan NEWS diruang perawatan.

\section{DAFTAR PUSTAKA}

Australasian College For Emergency Medicine. (2016). Guidelines OnThe Implementation Of The
Australasian Triage Scala In Emergency Department

Bernstein, S. L., Aronsky, D., Duseja, R., Epstein, S., Handel, D.,Hwang, U., et al. (2009). The effect of emergency department crowding on clinical oriented outcome. Academic Emergency Medicine, 16(1), 1-10

Kartikawati, N., (2013). Buku Ajar Dasar-dasar Keperawatan Gawat Darurat. Jakarta: Salemba Medika

Mathukia C, Fan W, Vadyak K, Biege C, and Krishnamurthy M, (2015). Modified Early Warning System improves patient safety and clinical outcomes in an academic community hospital. J Community Hosp Intern Med Perspect. 2015; 5(2): DOI. 10.3402/jchimp.v5.26716.

Oman, S. (2008) Panduan Belajar Keperawatan Emergensi. Jakarta: EGC

Smith MEB, Chiovaro JC, O'Neil M, et al (2014). Early Warning System Scores: A Systematic Review [Internet]. Washington (DC): Department of Veterans Affairs (US); 2019 Jan. BACKGROUND. Available from: https://www.ncbi.nlm.nih.gov/books/ NBK259029/

Winarno, I (2018). Early Warning System Di Rumah Sakit. http://rsudajibarang.banyumaskab.go. id/news/26307/early-warning-systemdi-rumah-sakit\#.XMW_iokzbIU 